\title{
DESAIN INSTALASI PENGOLAHAN LEACHATE (IPL) DI TPA ENTIKONG KABUPATEN SANGGAU
}

Yendi Friadi ${ }^{1)}$, Marsudi ${ }^{2)}$, Winardi Yusuf ${ }^{1)}$

${ }^{1)}$ Program Studi Teknik Lingkungan Jurusan Teknik Sipil Fakultas Teknik Universitas Tanjungpura, Pontianak

${ }^{2)}$ Program Studi Teknik Sipil Jurusan Teknik Sipil Fakultas Teknik Universitas Tanjungpura, Pontianak Email: yendifriadi@yahoo.o.id

\begin{abstract}
ABSTRAK
Leachate dapat didefinisikan sebagai cairan yang menginfiltrasi melalui tumpukan sampah dan telah mengekstraksi material terlarut maupun tersuspensi. Sistem instalasi pengolahan leachate bergantung pada debit dan karaktersitik leachate itu sendiri. Tujuan dari penelitian ini adalah memperkirakan debit leachate yang dihasilkan oleh TPA Entikong sebagai acuan dasar perancangan/desain instalasi pengolahan leachate, merencanakan sistem instalasi pengolahan leachate di TPA Entikong Kabupaten Sanggau serta mengetahui anggaran biaya yang diperlukan dalam perancangan IPL berdasarkan sistem pengolahan yang digunakan.Tahapan untuk mengolah dan menghitung data meliputi perhitungan debit leachate dan mendesain/merancang IPL. Debit leachate dihitung dari rata-rata hujan maksimum bulanan, dari data beberapa tahun atau dengan menggunakan metode neraca air yaitu metode pendekatan Thornhtwaite. Faktorfaktor yang berpengaruh terhadap kuantitas leachate dalam metode neraca air ini adalah presipitasi, evapotransipitasi, surface run-off dan soil moisture storage. Proses desain IPL terdiri dari penentuan letak IPL, penentuan jenis pengolahan, penentuan sistem pengolahan yang ada di Indonesia, pemilihan desain IPL, melakukan perhitungan hidroulik terhadap desain sistem IPL terpilih, menentukan layout bangunan IPL, membuat gambar rancangan, perhitungan anggaran biaya serta membuat spesifikasi teknis pembuatan IPL.Berdasarkan hasil perhitungan menggunakan metode Thornthwaite didapat perkolasi tertinggi sebesar 185,43 mm dan diketahui luas area timbunan sampah TPA Entikong sebesar 1,06 Ha maka diperoleh nilai debit leachate sebesar $65,52 \mathrm{~m}^{3} /$ hari. Kandungan organik (BOD) yang terdapat dalam leachate mempunyai nilai BOD sebesar $10.000 \mathrm{mg} / \mathrm{L}$, sehingga metode pengolahan biologi sangat tepat digunakan untuk mengolah leachate di TPA Entikong. Sistem pengolahan yang digunakan adalah pengolahan secara biologi. Unit-unit pengolahan leachate TPA Entikong yang direncanakan adalah bak ekualisasi, kolam anaerobik, kolam fakultatif, kolam maturasi dan constructed wetland. Besarnya total biaya yang dibutuhkan adalah Rp. 1.375.000.000,00
\end{abstract}

Kata-kata kunci : BOD, Leachate, Thornthwaite

\section{ABSTRACT}

Leachate can be defined as a liquid that can infiltrate through pile of waste and has extracted dissolved or suspended materias. The instalation system of leachate proccesing depends on the discharge and the characteristics of the leachate itself. The purpose of this research is to estimate the leachate discharge that is produced by TPA Entikong as a basic reference design / design of leachate treatment, planning of the instalation system at TPA Kabupaten Sanggau and to know the budget needed to design IPL from the system proccesing used. The steps to process can to count the data consist of counting leachate discharge and to design/plan IPL. Leachate discharge is counted from the average monthly maximum rain, from a couple of past years, or using water balance method that is a thornthwaite. Factors that weigh on the the leachate quantity in this water balancing method is evapotransipitation, surface run-off and soil moisture storage. The IPL design procces consists of the IPL placement, determing the type of processing, determing the type of system used in indonesia, choosing the IPL design, chosing the IPL building layout, creating a architecture design, counting the budget cost and creating a specification of making an IPL. Based on the calculation using the thornthwaite method we obtained the highest percolation is $185.43 \mathrm{~mm}$ and a known area of landfill waste piles Entikong of $1.06 \mathrm{Ha}$, so the leachate discharged obtained is $65.52 \mathrm{~m}^{3} /$ hari. Organic content (BOD) that is found in leachate has a value of $10,000 \mathrm{mg} / \mathrm{L}$, so the biological method used is appropriate to use to process leachate in Entikong TPA. The system procces used is by biological procces. The leachate proccesing unit in TPA Entikong that is planned is an ecolation vessel, Anaerobic pond, facultative pond, maturation pond, and a constructed wetland. The total cost needed is $R p .1,375,000,000.00$

Key Words : BOD, Leachate, Thornthwaite 


\section{PENDAHULUAN}

Sampah merupakan permasalahan yang timbul di kota-kota besar yang ada di Indonesia. Dewasa ini pembangunan yang banyak dilaksanakan secara besar-besaran, di daerah perkotaan di Indonesia telah membawa dampak negatif terhadap lingkungan. Semakin meningkatnya jumlah pertumbuhan penduduk yang tinggi disertai kemajuan tingkat perekonomian, maka akan sangat mempengaruhi peningkatan jumlah volume sampah baik secara kuantitatif maupun kualitatif. Apabila tidak dikelola dengan baik akan mempengaruhi tingkat kebersihan dan mencemari lingkungan yang pada akhirnya akan menurunkan tingkat kesehatan masyarakat. Beberapa alternatif cara pun dilakukan untuk mengelola sampah demi terwujudnya kota bersih dan tidak mengganggu lingkungan, salah satu sub sistem dalam pengelolaan sampah yaitu adanya Tempat Pemrosesan Akhir (TPA) sampah.

Kasus pencemaran TPA yang secara potensial menimbulkan konflik sosial dan berakibat pada adanya pencemaran leachate. Dengan adanya perencanaan IPL di TPA Entikong Kabupaten Sanggau diharapkan dapat mencegah pencemaran lingkungan disekitar TPA. Sehingga dalam pengoperasian TPA Entikong nantinya akan sesuai dengan persyaratan teknis dan lingkungan yang meliputi fasilitas perlindungan lingkungan seperti lapisan dasar kedap air, saluran pengumpul leachate, pengolahan leachate, dan ventilasi gas (gas metan).

\section{TINJAUAN PUSTAKA}

Sampah dapat didefinisikan sebagai semua buangan yang dihasilkan dari berbagai aktivitas manusia dan hewan yang berupa padatan, yang dibuang karena sudah tidak berguna atau tidak diperlukan lagi. Pengelolaan sampah merupakan kegiatan dalam pengaturan terhadap timbulan sampah, penyimpanan sementara, pengumpulan, pemindahan atau pengangkutan dan pengolahan serta pembuangan sampah dengan menggunakan suatu cara sesuai dengan prinsip-prinsip yang berhubungan dengan kesehatan masyarakat, ekonomi, teknik, perlindungan alam, keindahan dan pertimbangan lainnya, serta mempertimbangkan masyarakat luas (Tchobanoglous et.al.,1993).

\section{Leachate (Air Lindi)}

Leachate dapat didefinisikan sebagai cairan yang timbul dari hasil dekomposisi biologis sampah yang telah membusuk yang mengalami pelarutan akibat masuknya air eksternal ke dalam urugan atau timbunan sampah. Leachate disebabkan oleh terjadinya presipitasi cairan ke TPA, baik dari resapan air hujan maupun kandungan air pada sampah itu sendiri. Leachate bersifat toksik karena adanya zat pengotor dalam timbunan yang mungkin berasal dari buangan limbah industri, debu, lumpur hasil pengolahan limbah, limbah rumah tangga yang berbahaya, atau dari dekomposisi yang normal terjadi pada sampah. Apabila tidak segera diatasi, landfill yang dipenuhi leachate dapat mencemari lingkungan, terutama air tanah dan air permukaan. Hampir di semua TPA, leachate terdiri dari cairan yang terdapat di TPA dari sumber eksternal, seperti permukaan drainase, air hujan, air tanah, dan air dari bawah tanah dan cairan yang diproduksi dari dekomposisi sampah (Tchobanoglous et al., 1993). Sampah pada timbunannya akan mengalami proses dekomposisi yang ditandai dengan perubahan fisis, biologis, dan kimiawi. Dekomposisi yang terjadi pada landfill dipengaruhi oleh pemadatan, kelembapan, kehadiran materi penghambat, laju pengaliran air, temperatur, tersedianya $\mathrm{O}_{2}$, populasi mikrobiologis yang dipengaruhi keadaan tanah penutup dan tipe dari sintesa yang terjadi, sifat-sifat heterogenisasi sampah, sifat-sifat fisik, kimiawi dan biologis (Peavy et al.,1986). Variasi didalam komposisi leachate dipengaruhi oleh beberapa faktor, antara lain: komposisi dan umur sampah, lokasi dan pengoperasian serta kondisi landfill, iklim dan kondisi hidrogeologi, kelembaban, temperatur, pH, dan tingkat stabilisasi (Tchobanoglous et al., 1993).

\section{Karakteristik Leachate}

Persoalan utama dalam pengolahan leachate adalah penentuan kualitas desain dari leachate yang akan diolah di IPL. Kualitas desain leachate sangat bergantung pada sampling leachate yang dilakukan. Pada umumnya karakteristik leachate adalah cairan berwarna coklat, mempunyai 
kandungan organik (BOD dan COD) tinggi, kandungan logam berat biasanya juga tinggi dan berbau septik.

Komposisi zat kimia dari leachate berubah-ubah tergantung pada beberapa hal antara lain (Enri Damanhuri, 1995) :

1) Karakteristik dan komposisi sampah

Secara alami, fraksi organik sampah dipengaruhi oleh degradasi sampah dalam landfill dan juga kualitas leachate yang diproduksi. Hadirnya zat-zat beracun bagi bakteri akan memperlambat proses degradasi.

2) Jenis tanah penutup landfill

Porositas tanah penutup landfill akan mempengaruhi banyak tidaknya air hujan yang masuk ke dalamnya yang nantinya juga akan mempengaruhi jumlah leachate yang dihasilkan. Untuk itu diperlukan persyaratan khusus bagi tanah penutup harian maupun tanah penutup akhir.

3) Musim

Pergantian musim akan memberikan dampak yang berbeda pada jumlah produksi leachate dan juga konsentrasinya. Pada musim penghujan jumlah leachate yang dihasilkan umumnya akan lebih besar namun memiliki konsentrasi yang lebih rendah dibandingkan pada saat musim kemarau karena air hujan yang masuk ke dalam landfill akan berperan sebagai pengencer.

4) $\mathrm{pH}$ dan kelembaban

Nilai $\mathrm{pH}$ akan mempengaruhi proses kimia yang merupakan basis dari transfer massa dalam sistem leachate sampah.

5) Umur timbunan (usia landfill)

Usia landfill dapat tercermin dari variasi komposisi leachate dan jumlah polutan yang terkandung. Umur landfill berpengaruh penentuan karakteristik leachate yang akan diatur oleh tipe proses stabilisasi.

Kandungan bahan organik dan bahan kimia yang tinggi pada leachate, jika tidak dilakukan pengolahan dengan baik akan menjadi sumber pencemar bagi badan air penerima, air tanah maupun topsoil tanah sebagai tempat tumbuhan mendapatkan nutrisi. Keberadaan leachate tanpa pengolahan yang baik pad akhirnya akan menjadi sumber penyakit bagi penduduk sekitarnya. Kandungan logam berat yang tinggi juga akan sangat berbahaya, yang bisa menyebabkan cacat bahkan kematian. Seperti contoh, selain mencemari air tanah, sumur penduduk, juga bisa mencemari tambak, dimana leachate tersebut bersifat toksik terhadap ikan yang dibudidayakannya. Sehingga perlu dilakukan pengolahan leachate.

Dalam pengambilan sampel leachate, beberapa hal yang perlu diperhatikan adalah sebagai berikut :

1) Posisi pengambilan sampel

2) Waktu pengambilan sampel : apakah setelah hujan atau pada saat musim kemarau

3) Metode pengambilan sampel (apakah composit atau grab sampling).

Leachate yang berasal dari timbunan sampah yang baru mempunyai nilai BOD dan COD yang sangat tinggi, tetapi semakin lama umur landfill, maka kualitas leachate landfill juga akan menurun.

Sampah yang dibiarkan terbuka bukan hanya mengakibatkan pencemaran udara akibat bau. Sampah yang menggunung akan menghasilkan leachate (leachate) yakni limbah cair, baik yang berasal dari proses pembusukan sampah maupun karena pengaruh luar. Kedua hal itu akan memengaruhi kuantitas dan kualitas leachate. Kualitas leachate itu masih dipengaruhi komposisi atau karakteristik sampah yang dibuang, umur timbunan, dan pola operasional TPA. Semakin banyaknya leachate, maka semakin berpotensi untuk masuk ke dalam air tanah dan mencemari sumur. Leachate yang dihasilkan dari sampah mengandung senyawa pathogen dari beberapa senyawa kimia organik dan anorganik (Susanto, 2004). Selain itu juga mengandung amoniak, timbal dan mikroba parasit seperti kutu air (sarcoptes $s p$ ) yang menyebabkan gatal air.

Berdasarkan karakteristik dari leachate, pengolahan sangat diperlukan sebelum leachate dibuang ke badan air. Pengolahan terutama bertujuan untuk mengurangi kandungan bahan organik di dalam leachate, mengurangi kandungan nutrien seperti $\mathrm{NH}_{4}$ dan kandungan logam berat yang diperkirakan ikut larut didalam leachate. Pengolahan leachate bisanya merupakan kombinasi baik pengolahan 
fisik, kimia dan biologis. Pengolahan leachate merupakan salah satu dari penanganan efluen leachate yang dapat dilakukan.

\section{Timbulan Leachate}

Leachate adalah limbah cair yang timbul akibat masuknya air eksternal ke dalam timbunan sampah, melarutkan dan membilas materi-materi terlarut, termasuk juga materi organik hasil proses dekomposisi biologis. Dari sana dapat diramalkan bahwa kuantitas dan kualitas leachate akan sangat bervariasi dan berfluktuasi yang dapat dilihat pada Gambar 1 (Vesilind et al., 2002).

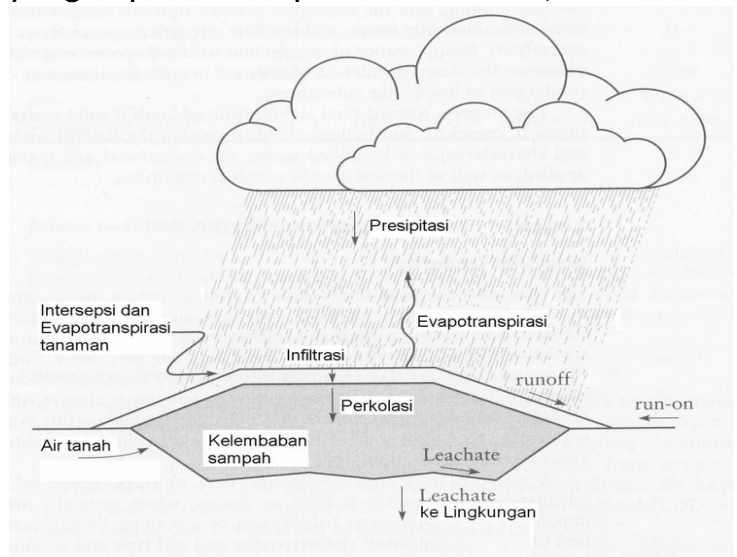

Gambar 1. Skema Terjadinya Leachate.

Gambar 1 menunjukkan proses terjadinya leachate yang dimulai dengan air hujan yang jatuh dan sebagian mengalami run off (RO) dan sebagian lain terinfiltrasi ke dalam tanah. Sebagian yang terinfiltrasi akan menguap melalui tumbuhan dan sisanya akan bergerak ke bawah dan akan membentuk leachate.

Leachate yang timbul setelah pengoperasian selesai, dapat diperkirakan dengan menggunakan suatu metoda yang disebut metoda neraca air (water balance method). Pendekatan yang biasa digunakan dalam memprediksi banyaknya leachate dari sebuah landfill adalah dengan metode neraca air yaitu metode Thorntwaite. Metode ini didasari oleh asumsi bahwa leachate hanya dihasilkan dari curah hujan yang berhasil meresap masuk ke dalam timbunan sampah (perkolasi). Beberapa sumber lain seperti air hasil dekomposisi sampah, infiltrasi muka air tanah, dan aliran air permukaan lainnya dapat diabaikan. Gambar 2 (Enri Damanhuri, 1995) berikut menggambarkan sistem input-output dari neraca air, dengan persamaan :

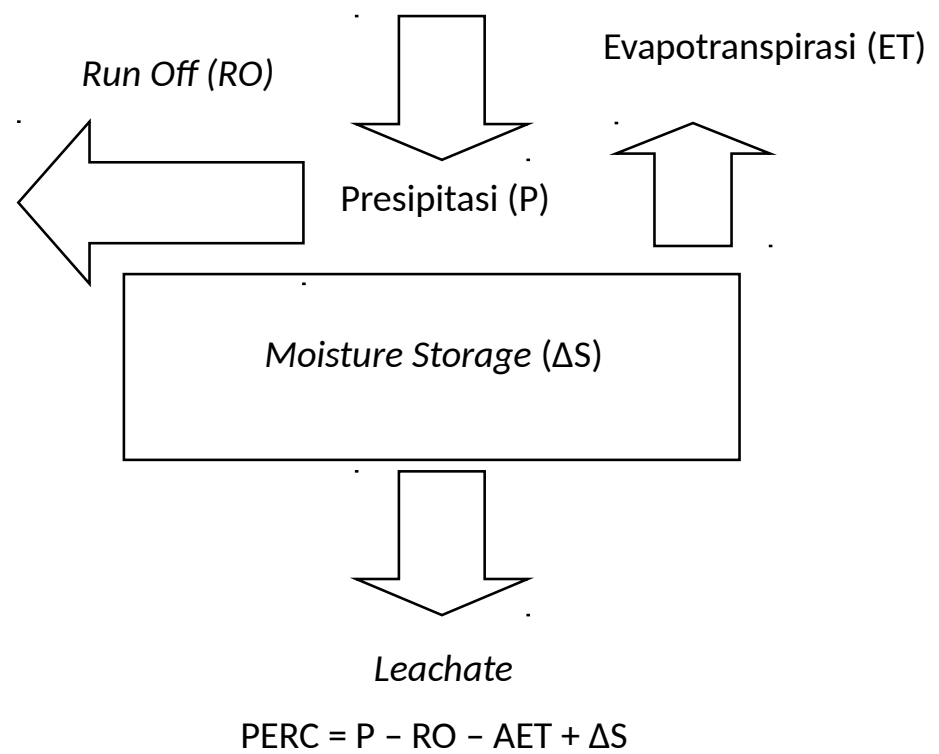

Gambar 2. Input - output konsep neraca air. 
Gambar 2 menunjukkan perhitungan neraca air Thornwaite, dengan menganggap aliran air ke bawah sebagai sistem berdimensi-satu, maka model neraca air yang dikembangkan oleh Thorntwaite, dapat digunakan untuk menghitung perkolasi air dalam tanah penutup menuju lapisan sampah di bawahnya. Salah satu keuntungan penggunaan tanah penutup akhir dalam mengurangi timbulnya leachate. adalah dari kemampuan penyerapan airnya. Air akan tertahan dalam tanah sampai menyamai angka field capacity-nya. Air yang terkandung oleh tanah bergantung pada jenis tanah dan berkurang dengan adanya evapotranspirasi dan bertambah kembali akibat infiltrasi. Tanpa adanya tanaman, setelah periode yang lama, tanah akan mempunyai kandungan air setinggi field capacity. Bila terdapat tanaman, maka akar mengambil air dan menguapkannya sehingga air akan berada di bawah field capacity tersebut. Pada saat air mencapai wilting points, maka akar tidak dapat lagi mengambil air dalam tanah tersebut yang terlihat pada Gambar 2 (Enri Damanhuri, 1995). Porositas, field capacity, dan wilting point mempunyai nilai antara 0 hingga 1. Porositas harus lebih besar dari field capacity, dimana perubahannya harus lebih besar dari wilting point. Wilting point harus lebih besar dari nol. Nilai dari porositas, field capacity dan wilting point tidak digunakan untuk liner, kecuali untuk nilai awal kadar air dari liner ke nilai porsitas.

Evapotranspirasi terjadi karena adanya penguapan dari tanah, dan transpirasi, yaitu pernafasan tumbuhan yang terdapat pada lapisan tanah penutup. Jumlah air yang hilang atau kembali ke atmosfer lebih besar pada transpirasi dibandingkan pada evaporasi. Tumbuhan berfungsi untuk menahan air agar air tidak diteruskan ke lapisan sampah, dan bagian daun akan menguapkan air tersebut. Evapotranspirasi yang sebenarnya terjadi (Actual Evapotranspiration = AET) tergantung persediaan air dalam tanah (soil moisture storage). Angka AET ini tidak sama dengan data ET dari stasiun meteorologi. Angka ET ini terjadi pada kondisi air yang selalu tersedia. Angka ET stasiun meteorologi ini disebut Potential Evapotranspiration (PET) atau evapotranspirasi maksimum yang dapat terjadi.

Bila soil moisture storage mendekati field capacity, ET mencapai nilai maksimumnya, tetapi bila soil moisture mendekati wilting point, ketersediaan air yang terbatas itu akan mengurangi laju ET. Metoda untuk mengetahui air yang dapat diserap setelah terjadi PET tertentu telah dikembangkan oleh Thornthwaite. PET dihitung dengan eksperimen maupun dengan metode empirik.

Umumnya tidak tersedianya data evapotranspirasi, maka nilai PET dikembangkan dari nilai evaporasi hasil pengukuran dilapangan dengan evaporimeter, yang memerlukan suatu faktor koreksi tertentu. Faktor koreksi ini dihitung dengan menggunakan perbandingan antara evapotranspirasi tanah berumput yang terairi dengan baik, dengan Pan evaporasi klas A, yaitu Pan yang terletak pada tanah berumput. Cara lain adalah dengan pendekatan empirik, seperti metode Thornthwaite.

\section{METODE PENELITIAN}

\section{Metode Pengumpulan Data}

Data Sekunder

1) Data administrasi Kecamatan Entikomg yang diperoleh melalui Badan Pusat Statistik (BPS) Provinsi Kalimantan Barat 2012.

2) Data hidrologi dan klimatologi yang diperoleh melalui Bagian Wilayah Sungai Kalimantan II (BWSK2).

3) Peta Kecamatan Entikong yang diperoleh melalui Badan Perencanaan Daerah (BAPEDA) Kabupaten Sanggau 2012.

4) Peta situasi dan topogafi yang diperoleh melalui Kementrian Pekerjaan Umum 2013.

5) Data tanah yang diperoleh melalui Kementrian Pekerjaan Umum 2013.

6) Data timbulan sampah yang diperoleh melalui Kementrian Pekerjaan Umum 2013.

7) Layout TPA Entikong yang diperoleh melalui Kementrian Pekerjaan Umum 2013.

8) Data kualitas leachate yang diperoleh melalui jurnal penelitian mengenai kualitas leachate di beberapa kota Indonesia. 


\section{Metode Analisis Data}

Perhitungan Debit Leachate

1) Selanjutnya dengan melihat pada tabel jumlah air yang dapat diserap oleh beberapa jenis tanah

2) Merata-ratakan data presipitasi dan temperatur secara bulanan

3) Menghitung potensi evapotranspirasi menggunakan metode Thornthwaite.

4) Menentukan nilai koefisien runoff (CRo) menggunakan nilai empiris yang dapat di lihat Menentukan nilai Runoff bulanan : Ro $=\mathrm{P}^{*}$ Cro

5) Menentukan nilai Infiltrasi :

$\mathrm{I}=\mathrm{P}-$ Ro

Menentukan air yang tersedia untuk penyimpanan : I - PET

6) Menentukan nilai Accumulated Water Lost (APWL), yaitu nilai negatif dari (I-PET) yang merupakan kehilangan air secara kumulasi.

7) Menentukan soil moisture storage (ST), yaitu banyaknya air yang tersimpan dalam tanah pada saat keseimbangan. Menghitung perubahan ST dari bulan terakhir (ST).

8) Mencari Actual Evapotranspiration,

9) Menentukan perkolasi (PERC)

\section{Tahap Desain/Perancangan IPL}

a) Menentukan jenis pengolahan

b) Teknik-teknik pengolahan leachate yang telah dikembangkan tersebut secara umum terbagi menjadi 3 metode pengolahan:

1. Pengolahan secara fisika

2. Pengolahan secara kimia

3. Pengolahan secara biologi.

c) Menentukan alternatif sistem pengolahan

d) Pemilhan sistem pengolahan

e) Perhitungan hidrolis terhadap desain IPL terpilih

f) Menentukan layout bangunan IPL

g) Membuat gambar desain IPL

h) Menghitung Rencana Anggaran Biaya (RAB)

i) Spesifikasi teknis

\section{HASIL DAN PEMBAHASAN}

\section{Perhitungan Metode Neraca Air Thornthwaite}

TPA Entikong memiliki jenis tanah silty loam dengan jumlah air yang tersedia sebesar $200 \mathrm{~mm} / \mathrm{m}$ dengan ketebalan tanah penutup di TPA Entikong adalah 0,5 m (C.V Oryza Consultant). Dari data curah hujan dan temperatur pada beserta data - data kondisi dilapangan maka dapat dihitung dengan menggunakan metode Thornthwaite. Adapun cara perhitungan dan hasil analisa neraca air dengan metode Thornthwaite adalah sebagai berikut :

Diberikan data klimatologi pada stasiun meteorologi kota kembayan tahun 2000 - 2010. Dengan posisi geografis terletak pada $0^{\circ} 49^{\prime}$ BS. Diketahui data desain landfill TPA Entikong adalah sebagai berikut :

- Tanah yang digunakan sebagai penutup akhir adalah: 14\% sand $16 \%$ clay, $66 \%$ silt

- Ketebalan tanah penutup 0,5 m dan memiliki $2 \%$ slope datar pada permukaannya.

- Sampah, tanah penutup, dan tanaman penutup ditempatkan pada saat bulan pertama yaitu pada permulaan perhitungan. Jadi, perkolasi yang terjadi sebelum penempatan tanah penutup akhir diabaikan.

- Permukaan ditanami tanaman rumput dengan akar sedang.

Hasil Perhitungan metode neraca air dengan metode pendekatan Thornthwaite :

Adapun hasil analisa neraca air dengan metode Thornthwaite dapat dilihat pada Tabel 1. 
Tabel 1. Hasil Perhitungan Neraca Air Thorntwhaite

\begin{tabular}{|c|c|c|c|c|c|c|c|c|c|c|c|c|c|}
\hline & Jan & Feb & Mar & Apr & Mei & Jun & Jul & Ags & Sep & Okt & Nov & Des & Jumlah \\
\hline T T rata-rata $\left({ }^{\circ} \mathrm{C}\right)$ & 26,14 & 26,71 & 26,81 & 26,81 & 27,27 & 28,01 & 27,01 & 27,19 & 27,07 & 26,76 & 26,45 & 26,31 & \\
\hline heat index(i) & 12,23 & 12,64 & 12,71 & 12,71 & 13,04 & 13,58 & 12,86 & 12,99 & 12,90 & 12,68 & 12,45 & 12,35 & 153,15 \\
\hline A & 3,85 & 3,85 & 3,85 & 3,85 & 3,85 & 3,85 & 3,85 & 3,85 & 3,85 & 3,85 & 3,85 & 3,85 & \\
\hline UPET $(\mathrm{cm})$ & 12,69 & 13,79 & 13,99 & 13,99 & 14,93 & 16,56 & 14,39 & 14,77 & 14,52 & 13,89 & 13,28 & 13,01 & \\
\hline UPET (mm) & 126,89 & 137,88 & 139,88 & 139,88 & 149,35 & 165,57 & 143,94 & 147,67 & 145,18 & 138,88 & 132,79 & 130,10 & \\
\hline $\mathrm{R}$ & 1,02 & 0,93 & 1,03 & 1,02 & 1,06 & 1,03 & 1,06 & 1,05 & 1,01 & 1,03 & 0,99 & 1,02 & \\
\hline PET & 129,43 & 128,23 & 144,08 & 142,68 & 158,31 & 170,53 & 152,58 & 155,05 & 146,63 & 143,05 & 131,46 & 132,70 & \\
\hline Presipitasi (mm) & 334 & 178 & 180 & 303 & 235 & 233 & 199 & 179 & 222 & 335 & 362 & 320 & 3078 \\
\hline Cro & 0,125 & 0,125 & 0,125 & 0,125 & 0,125 & 0,125 & 0,125 & 0,125 & 0,125 & 0,125 & 0,125 & 0,125 & \\
\hline $\mathrm{RO}(\mathrm{mm})$ & 41,72 & 22,28 & 22,46 & 37,85 & 29,34 & 29,09 & 24,90 & 22,32 & 27,69 & 41,87 & 45,27 & 39,99 & \\
\hline $\mathrm{I}(\mathrm{mm})$ & 292,03 & 155,96 & 157,21 & 264,94 & 205,40 & 203,62 & 174,28 & 156,22 & 193,83 & 293,12 & 316,89 & 279,94 & 2693,43 \\
\hline I-PET (mm) & 162,60 & 27,73 & 13,13 & 122,26 & 47,09 & 33,09 & 21,71 & 1,17 & 47,20 & 150,07 & 185,43 & 147,23 & 958,70 \\
\hline AccWL $(\mathrm{mm})$ & 0 & 0 & 0 & 0 & 0 & 0 & 0 & 0 & 0 & 0 & 0 & 0 & \\
\hline $\mathrm{ST}(\mathrm{mm})$ & 100 & 100 & 100 & 100 & 100 & 100 & 100 & 100 & 100 & 100 & 100 & 100 & \\
\hline$\Delta \mathrm{ST}(\mathrm{mm})$ & 0 & 0 & 0 & 0 & 0 & 0 & 0 & 0 & 0 & 0 & 0 & 0 & \\
\hline AET & 129 & 128 & 144 & 143 & 158 & 171 & 153 & 155 & 147 & 143 & 131 & 133 & 1735 \\
\hline PERC & 162,60 & 27,73 & 13,13 & 122,26 & 47,09 & 33,09 & 21,71 & 1,17 & 47,20 & 150,07 & 185,43 & 147,23 & \\
\hline $\begin{array}{l}\text { Cek: } P=P E R C+ \\
A E T+\Delta S T+R O\end{array}$ & 334 & 178 & 180 & 303 & 235 & 233 & 199 & 179 & 222 & 335 & 362 & 320 & \\
\hline
\end{tabular}

Sumber : Hasil Analisa 
Tabel 1 merupakan hasil perhitungan neraca air Thornthwaite. Nilai perkolasi maksimum terjadi pada Bulan November yaitu sebesar 185,43 mm. Nilai ini digunakan untuk menghitung besarnya timbulan leachate maksimum yang terjadi pada area TPA Entikong.

\section{Debit Leachate}

Debit leachate dihitung dari neraca air, kemudian diambil perkolasi kumulasi bulanan yang maksimum. Nilai perkolasi menentukan banyaknya timbulan leachate yang harus dikelola. Hal ini didasarkan bahwa leachate hanya dihasilkan dari curah hujan yang berhasil meresap masuk ke dalam timbunan sampah (perkolasi). Hal ini disebabkan desain lapisan dasar TPA Entikong terbuat dari lapisan kedap air (geomembran dan geotextile). Lapisan kedap air berfungsi untuk mencegah rembesan air leachate yang mengalir ke dasar TPA ke dalam lapisan tanah di bawahnya sehingga leachate yang dihasilkan sama dengan curah hujan yang berhasil masuk ke dalam timbunan sampah (perkolasi) yang selanjutnya menuju ke saluran pengumpul leachate hingga mengalir ke kolam pengolah leachate. Berdasarkan hasil perhitungan menggunakan metode Thornthwaite (Tabel 1) didapat perkolasi tertinggi sebesar $185,43 \mathrm{~mm}$ (Bulan November) dan diketahui luas lahan TPA Entikong sebesar 1,06 Ha maka diperoleh nilai debit pengolah leachate sebesar 1965,6 $\mathrm{m}^{3} / \mathrm{bulan}$. Adapun debit leachate (Q) yang diolah per hari adalah :

$Q_{\text {leachate }}=\frac{1965,6 \mathrm{~m}^{3} / \text { bulan }}{30 \text { hari } / \text { bulan }}=\frac{65,52 \mathrm{~m}^{8}}{\text { hari }}$

Nilai debit sebesar $65,52 \mathrm{~m}^{3} /$ hari akan dijadikan dasar sebagai debit leachate yang dihasilkan dari TPA Entikong yang selanjutnya akan dialirkan ke kolam pengolahan leachate.

\section{Kolam Anaerobik}

Kolam anaerobik dirancang untuk menerima beban organik (BOD) yang sedemikian tinggi (10.000 $\mathrm{mg} / \mathrm{L}$ ) yang dalam hal ini kolam mempunyai nilai oksigen terlarut yang sangat rendah. Kolam ini diletakkan dibagian awal sistem karena jenis kolam ini paling menguntungkan digunakan untuk mengolah air limbah yang mempunyai suatu kadar padatan yang tinggi. Padatan ini akan mengendap ke dasar kolam yang dalam hal ini padatan tersebut dicerna secara anaerobik.

Nilai $\lambda v$ dipilih $350 \mathrm{~g} / \mathrm{m}^{3}$-hari sebagai nilai maksimum untuk mencegah beban organik yang berlebihan dan juga dapat menghindari masalah bau. Pada suhu yang lebih tinggi atau daerah beriklim tropis seperti Kota Entikong, kolam pengolahan anaerobik akan memiliki beban volumetrik yang tinggi. Kriteria desain yang paling dipertimbangkan adalah suhu. Suhu yang panas lebih disukai, karena suhu optimum untuk desain berada di atas $25^{\circ} \mathrm{C}$. Waktu detensi hidrolis pada kolam anaerobik adalah 29 hari. Karena di awal operasi, kolam stabilisasi anaerobik akan memerlukan waktu 7 - 14 minggu untuk aklimatisasi bakteri. Setelah stabil dan berfungsi normal, waktu tinggal di kolam anaerobik bisa hanya 2 - 5 hari.

Kolam anaerobik dengan ukuran panjang $28 \mathrm{~m}$, lebar $14 \mathrm{~m}$, dan tinggi $5,5 \mathrm{~m}$ yang merupakan pengolahan pendahuluan dan mempunyai kedalaman \pm 5 meter yang berfungsi untuk menjaga kondisi kolam agar tetap dalam keadaan anaerobik (tidak ada oksigen) agar bakteri anaerobik dapat bekerja secara maksimum. Diasumsikan bahwa efisiensi kolam anaerobik mencapai $70 \%$, sehingga BOD efluen dari kolam anaerobik adalah $3.000 \mathrm{mg} / \mathrm{L}$

\section{Kolam Fakultatif}

Proses pengolahan air limbah yang terjadi pada kolam fakultatif terdiri dari dua bagian, yaitu pada lapisan atas kolam terjadi proses secara aerobik sedangkan pada bagian dasar kolam proses secara anaerobik. Kedalaman dari kolam fakultatif antara 1 - 2,4 meter, oksigen yang tersedia karena adanya angin dan ganggang (proses fotosintesis) tidak mampu menembus lapisan air di bagian dasar kolam. Kolam ini diletakkan setelah kolam anerobik karena efluen leachate dari kolam anerobik masih sangat tinggi yaitu $3.000 \mathrm{mg} / \mathrm{L}$. Kolam fakultatif ini dapat bekerja secara anaerobik dengan beban organik (BOD) yang tinggi dan secara aerobik. 
Kolam fakultatif merupakan pengolahan tahap kedua dari sistem IPL TPA Entikong. Proses pengolahan air limbah yang terjadi pada kolam fakultatif terdiri dari dua bagian, yaitu pada lapisan atas kolam terjadi proses secara aerobik sedangkan pada bagian dasar kolam proses secara anaerobik. Kolam dengan ukuran panjang $35 \mathrm{~m}$, lebar 17,5 m, dan kedalaman dari kolam fakultatif antara 1 - 2,4 meter(2 meter), dirancang agar oksigen yang tersedia karena adanya angin dan ganggang (proses fotosintesis) tidak mampu menembus lapisan air di bagian dasar kolam. Waktu detensi hidrolis pada kolam fakultatif adalah 14 hari. Karena, seperti halnya kolam stabilisasi anaerobik akan memerlukan waktu beberapa minggu untuk aklimatisasi bakteri. Setelah stabil dan berfungsi normal, waktu tinggal di kolam fakultatif bisa hanya 10 - 20 hari. Diasumsikan bahwa efisiensi kolam anaerobik mencapai $80 \%$, sehingga BOD efluennya adalah $600 \mathrm{mg} / \mathrm{L}$.

\section{Kolam Maturasi}

Kolam pematangan (kolam maturasi) digunakan sebagai tahap kedua dari kolam fakultatif. Fungsi utama kolam maturasi adalah penghancuran phatogen. Bakter faecal dan virus mati dengan kecepatan tinggi karena kondisi lingkungan yang tidak baik bagi organisme tersebut.

Kolam pematangan (kolam maturasi)dengan ukuran panjang $25 \mathrm{~m}$, lebar $12,5 \mathrm{~m}$ dan tinggi $2 \mathrm{~m}$ digunakan sebagai tahap kedua dari kolam fakultatif. Fungsi utama kolam maturasi adalah penghancuran phatogen. Bakter faecal dan virus mati dengan kecepatan tinggi karena kondisi lingkungan yang tidak baik bagi organisme tersebut. Kolam maturasi secara keseluruhan adalah aerobik dan dapat mempertahankan kondisi aerobik pada kedalaman sampai $3 \mathrm{~m}$. Akan tetapi kedalaman suatu kolam maturasi kebanyakan diambil sama dengan kedalaman kolam fakultatif yang bersangkutan $(2 \mathrm{~m})$. Ini disarankan dan biasanya paling tepat. Karena penghancuran virus-virus akan lebih baik dalam kolam yang dangkal daripada kolam yang dalam. Diasumsikan bahwa efisiensi kolam maturasi mencapai 60\%, sehingga BOD efluennya adalah $240 \mathrm{mg} / \mathrm{L}$.

\section{Wetland Jenis Subsurface Flow Systems (SFS)}

Wetland jenis SFS adalah constructed wetland yang terbuat dari parit atau kolam dengan lapisan kedap air dari tanah liat atau bahan sintetis di bawahnya. Kolam berisi media yang akan mendukung pertumbuhan tanaman air. Sistem ini dibuat dengan kemiringan elevasi 1-3\% antara inlet dan outlet. Kolam ini berfungsi untuk mengurangi kandungan logam berat dan BOD yang terdapat di dalam leachate.

Contructed wetland merupakan unit pengolahan terakhir dalam sistem IPL ini. Kolam dengan ukuran panjang 21,1 m, lebar 16,5 m dan kedalam 1,3 m ini berfungsi untuk menyerap logam berat yang terdapat pada leachate serta mengurangi kandungan BOD. Untuk menghasilkan efluen yang lebih baik maka penggunaan constructed wetland dapat menjadi alternatif pengolahan air limbah dengan biaya dan efiensi yang efektif. Constructed Wetlamds meliputi Free Water Surface (FWS) dan Subsurface Flow Systems (SFS). Sistem yang kedua melibatkan aliran bawah permukaan melalui media permeabel. Karena menggunakan tanaman air, untuk pengolahan sistem ini bergantung pada reaksi mikrobiologi. Jenis media (tanah atau batuan) berpengaruh terhadap sistem hidrolik pada wetland. Pada penelitian ini digunakan wetland jenis Subsurface Flow Systems (SFS) karena peluang polutan untuk berkontak dan mengalami penyerapan dalam sistem SFS lebih besar dibandingkan dengan jenis FWS sehingga penyisihan logam bisa sangat efektif. Efluen akhir dari kolam wetland adalah $<12 \mathrm{mg} / \mathrm{L}$.

\section{Perhitungan Rencana Anggaran Biaya (RAB)}

Perhitungan rencana anggaran biaya (RAB) merupakan suatu cara perhitungan harga satuan pekerjaan konstruksi yang dijabarkan per indeks bahan bangunan dan upah kerja dengan harga bahan bangunan dan upah pekerja berdasarkan standar daerah perencanaan untuk menyelesaikan harga pekerjaan dari konstruksi tersebut. Dari hasil perhitungan RAB diperoleh biaya sebesar Rp. 1.375.000.000,00. 


\section{KESIMPULAN}

Berdasarkan percobaan yang telah dilakukan dalam penelitian ini maka dapat dikemukakan beberapa kesimpulan sebagai berikut :

a.

Berdasarkan hasil perhitungan menggunakan metode Thornthwaite didapat perkolasi tertinggi sebesar $185,43 \mathrm{~mm}$ yaitu pada bulan november dan diketahui luas timbunan sampah TPA Entikong sebesar 1,06 Ha maka diperoleh nilai debit pengolah leachate sebesar 65,52m3/hari yang selanjutnya akan dialirkan ke kolam pengolahan leachate.

b.

Instalasi pengolahan leachate di TPA Entikong Kabupaten Sanggau direncanakan menggunakan alternatif sistem pengolahan secara biologi. Unit-unit pengolahan leachate TPA Entikong yang direncanakan adalah kolam anaerobik dengan waktu detensi 29 hari, kolam fakultatif waktu detensi 14 hari, kolam maturasi dengan waktu detensi 7 hari dan constructed wetland dengan waktu detensi 1,5 hari. Sebelum menuju ke sistem IPL, leachate terlebih dahulu menuju bak penampung/pengumpul leachate (ekualisasi) dengan waktu detensi 2 jam untuk memperkecil fluktuasi beban organik (BOD) dan beban hidrolis (Q).

c. Besarnya anggaran biaya yang dibutuhkan adalah Rp. 1.375.000.000,00 dengan rincian biaya pembuatan bak ekualisasi sebesar Rp. 15.570.200,00 biaya pembuatan kolam anaerobik sebesar Rp. 338.265.428,00 biaya pembuatan kolam fakultatif sebesar Rp. 419.084.900,00 biaya pembuatan kolam maturasi sebesar Rp. 227.096.216,00 biaya pembuatan constructed wetland sebesar Rp. 206.330.473,00 serta pekerjaan pipa sebesar Rp. $353.660,00$.

\section{UCAPAN TERIMAKASIH}

Dengan selesainya penelitian ini saya mengucapkan terima kasih yang sebesar-besarnya kepada ALLAH SWT, kedua orang tua, kedua dosen pembimbing yaitu Bapak Marsudi dan Winardi Yusuf serta kepada teman-teman Teknik 2007 dan semua orang yang telah berperan dalam membantu penelitian yang tidak dapat di ucapkan satu persatu. Harapan saya penelitian ini dapat bermanfaat bagi semua dan dapat dipergunakan sebagaimana mestinya.

\section{DAFTAR PUSTAKA}

Damanhuri, Enri. 1995. Teknik Pembuangan Akhir. Bandung: Jurusan Teknik Lingkungan ITB.

Peavy, S., Howard. Rowe, Donald R., dan Tchobanoglous, George. 1986. Environmental engineering. Singapore.

Tchobanoglous. 1993. Integrated Solid Waste Management Engineering Principles and Mangement Issues. New York: Mc Graw Hill Inc.

Vesilind, P. A., Warrel, W., dan Reinhart, D. R. 2002. Solid Waste Engineering. New York: McGraw-Hill Book Co 
